\title{
The Implementation of the Government Goods and Services Procurement Policy at the General Hospital of Sanggau Regency West Kalimantan Province
}

\author{
Hari Liewarnata \\ Institut Pemerintahan Dalam Negeri, Indonesia \\ Bahrullah Akbar \\ Badan Pemeriksa Keuangan, Indonesia \\ Murtir Jeddawi \\ IPDN, Indonesia \\ Sampara Lukman \\ IPDN, Indonesia \\ E-mail: hari.ptcba@gmail.com
}

Received: Feb. 5, 2019 Accepted: Jun. 20, 2019 Online published: Jul. 3, 2019

doi:10.5296/jpag.v9i2.14323

URL: https://doi.org/10.5296/jpag.v9i2.14323

\begin{abstract}
This study is associated with the implementation of the government goods and services procurement policy at the General Hospital of Sanggau Regency, West Kalimantan Province. In this case, the procurement refers to the procurement causing legal problems namely the procurement of surgical medical devices in fiscal year 2014. The theoretical structure of the research consists of the grand theory (government science), middle range theory (public policy theory), and applied theory (the implementation theory of Van Meter and Van Horn Public Policies). This study was employed qualitative research approach. In addition, the secondary data collection was carried out by using library research. Meanwhile, the primary data collection was conducted by applying interview techniques and observation that involved 10 research informants determined by purposive sampling technique. The results of
\end{abstract}


this study were analyzed by the researcher by entailing six variables of Van Meter and Van Horn. The results of this study indicated that there was an alleged criminalization by Government Internal Supervisory Apparatus (GISA) through the results of an audit on the procurement of surgical medical devices at the General Hospital of Sanggau regency in fiscal year 2014. Basically, the reason why the GISA stipulated the State losses is due to the emergence of an indication of a conspiracy among auction participants referring to the explanation of article 83, paragraph (1) the letter e on Presidential Regulation No. 70 Year 2012, without involving Procurement Service Unit (PSU) and/or the working groups of PSU, including the existence of contract value differences with the real value of provider purchases and VAT. The cause of the criminalization of the GISA audit results raising legal problems is presumably resulted from the fact that the audit carried out by GISA was not based on the GISA audit standards. Moreover it was not objective and unprofessional. The results demonstrated that the state losses determined by GISA were grounded on 1) the misinterpretation on the conspiracy indications in the explanation of article 83 paragraph (1), the letter e, Presidential Regulation No. 70 Year 2012 carried out by GISA; 2) incorrect assumptions which are not in accordance with the facts conveyed by GISA in the treatise of the audit results used as the basis for determining state losses; 3) GISA does not understand the mechanism and system for implementing procurement stipulated by the Government in which it should be carried out electronically/(e-procurement); 4) State Loss Calculation Method performed by GISA by finding out the difference between the value of the contract and the real value of the purchase of the provider based on the incorrect interpretation regarding the indications of conspiracy in the explanation of the article 83 paragraph (1) the letter e, Presidential Regulation No. 70 Year 2012. As a result, the State losses that GISA's stipulated become baseless; 5) The existence of the alleged GISA audit is carried out based on emotions, subjectivity, motives and certain interests. The researcher proposes several suggestions and the "SO\&R by hari" model that can be analyzed by using 1 dimension/variable (variable policy standard, objective \& resources) on new concepts obtained by the researcher regarding the Implementation of Government Goods and Services Procurement Policy, which is a simplification and refinement of the Van Meter and Van Horn theories on Public Policy Implementation, and a new framework which is specific and focused on the research related to government goods and services procurement.

Keywords: policy implementation, procurement of goods and services, e-procurement, GISA audit standards, audit criminalization

\section{Introduction}

This study is related to the implementation of the government goods and services procurement policy in the procurement of surgical medical devices at the General Hospital of Sanggau regency in fiscal year 2014 causing legal problems due to the results of the GISA audit. Electronic procurement (e-procurement) obligued by the government since 2012 for certain ministries and applied in 2013 and based on the study of the government will gain the warranty of the effectiveness on the government goods and services to apply the principles of the efficient, effective, transparent, open, competitive, fair/non-discriminatory and accountable procurement in accordance with the Presidential Regulation No. 54 Year 2010 as 
amended by Presidential Regulation No. 70 Year 2012. The legal problems in the intended procurement "can be revealed in this study through the existing secondary data", in the form of:

1. Minutes of the results from the procurement audit of surgical medical devicrs at the General Hospital of Sanggau regency in fiscal year 2014;

2. The CMO response letter towards the minutes of the results of GISA audit;

3. The Results of GISA Audit Report, No: SR-558/PW14/5/2016 on December 7, 2016;

In identifying the problems which are indetifiction approachs to show research perspectives according to formal objects of the government, science becomes a relevant scientific object, and at the same time, it demonstrates the characteristics of a scientific discipline in which the object of the governance is the implementation of the government functions by the central and regional governments in order to achieve the objectives of administering the government, namely the realization of community welfare.

Indentification of poblems is linked to the legal issues presented in the minutes of the GISA audit results used as the basis of GISA to determine State losses for the procurement of surgical medical instruments in the General Hospital of Sanggau regency in fiscal year 2014, including 1) the budgeting mechanism which is not based on the needs and specifications of the equipment to be held; 2). The management of Owner Estimate (OE) uses a pricelist which has stated that the price offered includes tue Value Added Tax (VAT), but the Commitment Making Official (CMO) adds the VAT as a component of OE; 3) Bidding documents of other tender participant companies are uploaded to Electronic Procurement Services (LPSE) made by the auction winner company; 4) The auction winner company does not carry out procurement work; it is based on the clarification to the director of the provider company, and the procurement is carried out by another party; 5). GISA does not respond to the CMO response letter towards the minutes of the GISA audit; 6) The reasons/basis for determining State losses carried out by GISA are based on the indications of conspiracy; 7) the method for calculating State losses is carried out by GISA by reducing the amount of the contract value with the real value of provider purchases and VAT.

This study is limited to the disclosure of the identification of the above problems based on primary and secondary data. It attempts to make the study clear, affordable and can be analyzed in according with the Van Meter and Van Horn public policies, and the implementation model with the formulation of a problem focused on the implementation of procurement policies for surgical medicine at the General Hospital of Sanggau regency in fiscal year 2014.

\section{Theoretical Framework}

Hill and Hupe (2002: 45) explained the model of policy implementation according to Van Meter and Van Horn, as follow:

Van Meter and Van Horn go on to suggest a model in which six variables are linked dynamically to the production of an outcome performance; the six variables (surely are in fact clusters of variables) are: 


\section{Macrothink}

1. Policy standard and objective, which elaborate on the overall goals of the policy decision to provide concrete and more specific standards for assessing performance;

2. The resources and incentives made available;

3. The quality of inter-organizational relationships (we find in their discussions of this, as in so much of the American literature on implementation, an extensive discussion of aspects of federalism);

4. The characteristics of the implementation agencies, including issues like organizational control but also, going back surely to inter-organizational issues, the agency's formal and informal linkages with the policy- making or policy enforcing body;

5. The economic, social and political environment; and

6. The disposition or response of the implementers, involving three elements: their cognition (comprehension, understanding) of the policy, the direction of their response to it (acceptance, neutrality, rejection) and the intensity of that response.

The Van Meter and Van Horn Policy Implementation Model can be seen in the following chart.

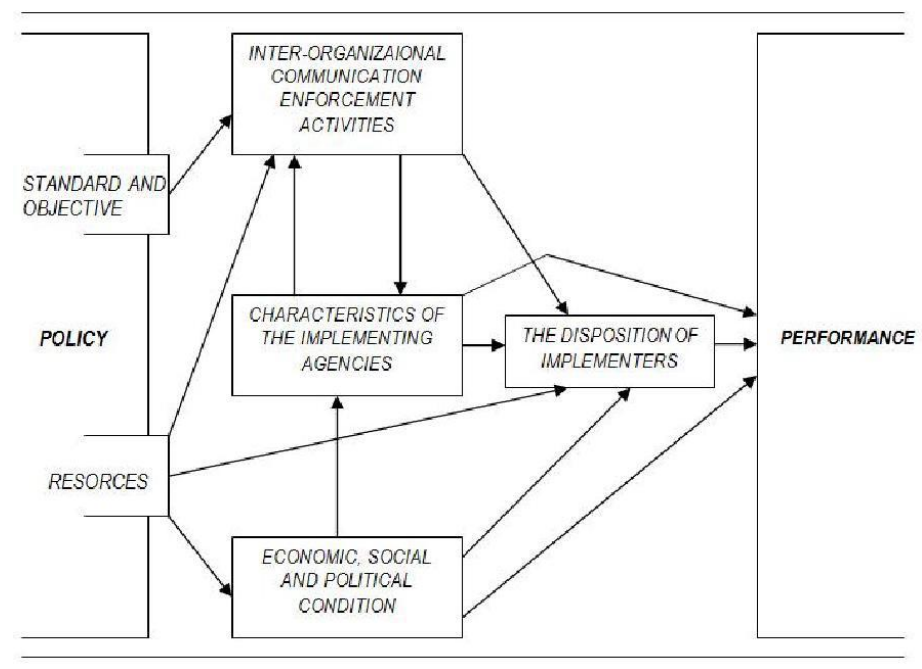

Figure 1. The implementation model of Van Meter and Van Horn policies

Source: "Hill and Hupe (2002:45)".

Van Meter and Van Horn (1975: 462) are explained below.

"Six variables which shape the linkage between policy and performance; this model not only specifies the relationships between the independent variables and the ultimate dependent variable of interest, but also makes explicit the relationships among the independent variables". 


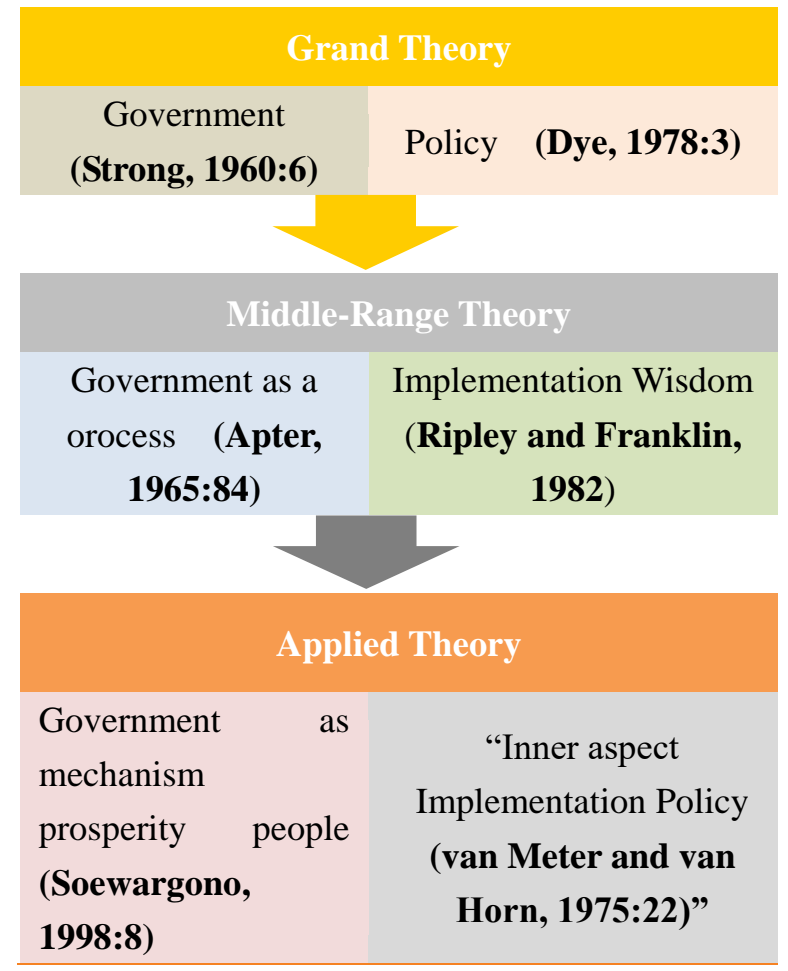

Figure 2. Theory Flow

\section{Research Methodology}

The research approach refers to the explanation of the research paradigm suggested by: 1 . Creswell (1994), namely: "The paradigm of qualitative research is essentially derived from American cultural and sociological anthropology (Kirk \& Miller, 1986)". However, the paradigm has been recently adopted by educational researchers (Borg \& Gali, 1989). "The purpose of qualitative research is to understand situations, events, groups or certain social interactions (Locke, Spirduso, \& Silverman 1987).

2. This research can be interpreted as an investigative process in which researchers gradually interpret a social phenomenon by distinguishing, comparing, duplicating, analogizing and classifying research objects (Miles \& Huberman, 1984).

3. Marshall and Rossman (1989) stated, "This study involves researchers to explore the settings of researchers; researchers enter the world of informants through continuous interaction, seeking informants' meanings and perspectives";

4. Creswell (2012) suggests "the synthesis from general assumptions about the characteristics of qualitative research that have been proposed by a number of researchers";

Grounded on the explanations above, this study was intended to reveal perceptions and experiences of informants and their ways of interpreting various things related to the phenomenon of the implementation of government goods and services procurement policies in Sanggau regency, at General Hospital as stated by Fraenkel \& Wallen (1990); Locke et al. (1987), and Merriam (1988). Hence, through the analysis method "observers triangulation", 
this study was aimed at understanding many realities as intended by Lincoln \& Cuba (1985).

\section{Data Analysis Stages}

By using data classification, the data analysis is carried out through the following stages of analysis:

1. Analysis of secondary data includes the presentation of data and analysis of data generated from documents and other data sources. Secondary data analysis aims to describe the general description of the research locus and describe the policy of procurement of surgical medical devices at the General Hospital Sanggau regency in fiscal year 2014;

2. Analysis of primary data entails the presentation, review, interpretation, and conclusion. Primary data analysis attempts to describe and discuss the implementation of government goods and services procurement policies, especially the procurement of surgical medical instruments at the General Hospital of Sanggau regency in fiscal year 2014.

3. Data analysis carried out according to the the implementation model of Van Meter and Van Horn public policies was developed by using the Triangulation of Observers method. This analysis method refers to (1) the viewpoint of the users of goods and services; (2) the suppliers' viewpoints of goods and services; and (3) stakeholders' perspectives.

4. Data analysis is not only to answer research questions according to the Van Meter and Van Horn public policy implementation approach, but at the same time it also attempts to obtain an empirical finding (research finding) that can be used as the basis for the preparation of new concepts.

\section{Research Results and Discussion}

The implementation of the government goods and services procurement at the general hospital of Sanggau Regency

The implementation of the policies for the procurement of surgical medical devices at the General Hospital of Sanggau regency in fiscal year 2014 is categorized as the implementation of public policy. According to Ripley and Franklin, policy implementation refers to a series of activities or actions that accompany statements about the objectives and program outcomes that government officials want to achieve. A series of activities or actions takes place when a law has been established to implement the program.

Analysis of the Implementation of Government Goods and Services Procurement Policy According to Van Meter and Van Horn

In the context of the implementation of the policy for the procurement of surgical medical devices at the General Hospital of Sanggau regency in fiscal year 2014, Van Meter and Van Horn emphasize the principles of the procurement of government goods and services which become the fundamental statement or general or individual truth which is used as a guide for thinking and acting. The principles of procurement are governed by Presidential Regulation No. 54 Year 2010 as amended by Presidential Regulation No. 70 Year 2012 in realizing eficient, effective, transparent, open, competitive, fair/non-discriminatory and accountable 
principles.

The engagement of a procurement agreement that is bound by the principle of freedom of contract involves: the principle of pacta sunt servanda, principle of equality, privity of contract principle, the principle of consensual, and principle of good faith. Normatively, the agreement/contract letter agreed and signed by the CMO and the provider should be in accordance with the provisions of the article 1338, paragraph (1) of the Civil Code stating that all agreements made legally are applied as Laws for those who make it.

The main tasks of the CMO and their authority have been regulated based on "Article 11 of the Presidential Regulation No. 54 Year 2010 as amended by Presidential Regulation No. 70 Year 2012". Related to legal issues in the procurement of surgical medical devices at the General Hospital of Sanggau regency in fiscal year 2014 occurred as a result of State losses in the GISA audit results stipulated due to "an indication of conspiracy referring to the explanation of the article 83 paragraph (1) the letter e, Presidential Regulation No. 70 Year 2012, where the reason or basis of the GISA is incompatible and contrary to the electronic procurement (e-procurement) system obligued by the government. Even GISA is carried out with an interpretation related to the indications of improper conspiracy or open misinterpretation by GISA, or GISA has not yet understood the indications of conspiracy conveyed in the explanation of article 83 paragraph (1) the letter e, Presidential Regulation No. 70 Year 2012. Consequently, the results of the GISA audit are allegedly contrary to the GISA audit Standards and Law No. 15 Year 2004 concerning on examining the management and responsibility of State finances, in which Article 1 paragraph (1) Of Law No. 15 Year 2004 states that inspection is a process of problem identification, analysis and evaluation carried out independently, objectively, and professionally based on inspection standards in order to assess the correctness, accuracy, credibility and reliability of information regarding the management and responsibility of State finance. Moreover, according to the Minister of Apparatus Empowerment Regulation Country No. 5 Year 2008 concerning on GISA Audit Standards, audit entails a process of problem identification, analysis and evaluation of evidence carried out independently, objectively and professionally based on audit standards in order to assess truth, accuracy, credibility, effectiveness, efficiency and reliability information on the implementation of duties and functions of government agencies. Audit standards based on Minister of State Apparatus Empowerment Regulation No. 5 Year 2008 is a minimum quality criterion or measure for conducting audit activities that should be guided by GISA.

In this case, GISA determines the State's loss by making its own interpretation which is not appropriate as it should be regarding the indications of the conspiracy in the explanation of article 83 paragraph (1) the letter e Regulation No. 70 Year 2012, so that the misinterpretation was intentionally made with the aim of obtaining reasons for determining State losses since the results of the GISA audit related to the implementation of the contents of the contract did not reveal any irregularities that could be used as an excuse to determine state losses.

The results of the study indicated that misinterpretation related to indications of the conspiracy carried out by the GISA on the explanation of article 83 paragraph (1) the letter e 
Presidential Regulation No. 70 Year 2012 covered:

\section{All offers from the providers approach the $\mathrm{OE}$}

According to GISA interpretation, if the total bidding value of all auction participants is close to the total value of the SPE, it indicates that the indication element of the intended conspiracy is fulfilled. According to the expert and secondary data, the entire offer shows that the details of the OE that should be confidential as stipulated in Article 66 paragraph 3, have been violated or leaked to the providers. It means that the details of the offer conveyed by all participants approached the details of the OE; they do not compare the bidding value of the participants to the total value of the SPE that has been announced to all bidders as interpreted by GISA.

2. There are similarities in terms of technical documents such as work methods, materials, tools, analysis of technical approaches, unit prices, and/or specifications of goods offered (brands/types) and/or technical support.

According to GISA's interpretation, there is similarity of technical documents based on the presence of the same tables in all bids. It is stated that they have fulfilled the indicative elements of the conspiracy. According to the expert and secondary data, this point should refer to violations of the prohibitions set out in Legislation no. 5 Year 2009 concerning on the agreements that are prohibited, including Article 4 concerning oligopoly paragraph 1 and 2, namely paragraph (1) stating that business doers are prohibited from making agreements with other business doers to jointly control the production and or marketing of the goods and or services which may result in monopolistic practices or unfair business competition. In addition, paragraph (2) states that business doers should be suspected or assumed to jointly control the production and or marketing of goods and or services, as referred to in paragraph (1). If 2 (two) or 3 (three) business doers or groups of business doers control more than $75 \%$ (seventy-five percent) market share of a particular type of goods or services, unlike what GISA interpreted.

\section{The participation of several goods/services providers in 1 (one) control.}

According to GISA's interpretation, if there is a recognition from 2 other companies that participated 8 offers conveying the reasons for participating in submitting the offer only as a companion company, it indicates that they have fulfilled the indication element of the conspiracy intended. According to the expert and secondary data, the indication refers more to the prohibition stipulated in Law No. 5 Year 2009 article 26 and 27, namely: Article 26 stating that a person who occupies the position of director or commissioner of a company, it is forbidden to concurrently become a director or commissioner of another company when the companies: (i) are in the same relevant market; or (ii) have a close relationship in the field and or type of business; or (iii) collectively can dominate the market share of certain goods and or services, which can lead to monopolistic practices and or unfair business competition; Article 27 states that business doers are prohibited from holding majority shares in several similar companies that carry out business activities in the same field in the same relevant market, or establish several companies that have the same business activities in the same 
relevant market if the ownership results in: (i) one business doer or one group of business doer controls more than $50 \%$ (fifty percent) of the market share of a particular type of goods or services; (ii) two or three business doers or groups of business doers control more than $75 \%$ (seventy five percent) of the market share of a particular type of goods or services, unlike what GISA interpreted.

4. There are similarities/errors in the contents of the bidding documents, including similarity/typing errors, composition, and format of writing

According to GISA's interpretation, in this case GISA does not declare the fulfillment of the intended indication. What should be according to the expert and secondary data is that this indication is frequently found in the offers originating from one business group or different group/company but using the same bidding force. The practice of using supply makers shows that providers have limited capability, but have strong motivation to win the election. The similarity/error of technical documents among the offers can be seen including the similarity of the document format, unit price analysis, and so forth.

\section{The bid guarantee is issued from the guarantor which is equal to the sequential serial number}

According to GISA's interpretation, due to the fact thay there is no guarantee serial number for all sequential participants, the indication can eventually be fulfilled by looking up to the stamp serial number which is attached to 2 (two) guarantee offers that happen to have the stamp serial number 2 in the last sequential numbers. Therefore, according to GISA, it is found that there is a serial number guaranteeing consecutive offers. According to the expert and secondary data, what should be stated is that the offer guarantee issuer, especially those with a very wide network, should issue guarantees based on the serial number of the issuance. Hence, the issuance of collateral offers collectively, unlike the GISA's interpretation which is seemingly not objective. For this reason, the results of the audit and/or calculation of State losses carried out by GISA are alleged to be contrary to Law No. 15 Year 2004. In addition, they are contrary to the GISA Audit Standards and the purpose of procurement of goods and services carried out by the government. Also, they are contrary to the procurement system carried out electronically (e-procurement). Even the GISA error in interpreting indications of conspiracy in the Presidential Regulation which was made BASIS FOR SETTING COUNTRY LOSSES results in the loss of the State determined by GISA without having a basis. Besides, the indications of the conspiracy intended in Presidential Regulation No. 70 Year 2012 have been revoked/eliminated in the amendment to Presidential Regulation No. 16 Year 2016, proving that the indication of the partnership is not in accordance with the principle of procurement that has been carried out in full electronic (e-procurement).

\section{The conclusions of the results of the analysis with Van Meter and Van Horn variables}

\section{Standard Analysis of Policy and Objectives}

Standpoint: in addition to the misinterpretation made by GISA which is not appropriate for the indication of conspiracy in the explanation of article 83 paragraph (1) the letter e, Presidential Regulation No. 70 Year 2012, the occurrence of legal problems is also caused by 
the results of the GISA audit, including the assumptions used as the basis for determining the State's improper losses, such as those conveyed by GISA in the minutes of audit results, as well as the electronic procurement (e-procurement) system, which aims to increase transparency and accountability, market access and fair business competition, the efficiency of the procurement process, support the monitoring and auditing process, and fulfill real time access to information. Moreover, it is contrary to the results of the Audit Board of Indonesia (BPK RI) audit on LHP No. 17.C/LHP/ XIX.PNK/05/2015 On 5 May 2015 stating that there were no deviations related to the compliance with laws and regulations. Besides, it is contrary to LHP No. 17.B/LHP/XIX.PNK 5/2015 On May 5, 2015 stating that there were no deviations in the Internal control system. Furthermore, based on the statement of the Chair of the Inspector and Recipient Committee (DTAA), the investigation carried out by GISA on the physical results of procurement surgical instruments, the results indicated that there was no state loss related to the physical procurement, both specifications and number of tools, equipment requirements, equipment functions, brands and origin of the country. All are in accordance with the contents of the contract and the equipment is still functioning properly and used in the General Hospital of Sanggau regency. OE is determined by CMO based on Article 66 paragraph (7) and (8) Presidential Regulation No. 54 Year 2010 and Article 1 in conjunction with Article 2 paragraph (1) and (2) of the Minister of Finance Number 563/KMK.03/2003. Accordingly, when constructed and simultaneously evaluated for the procurement of surgical medical devices at the General Hospital of Sanggau regency in fiscal year 2014, it can be concluded as TROUBLESHOOTED TRUTH. The process starts from the planning of needs until the completion of all activities marked by the surrender of surgical devices by the provider to the CMO according to the contents of the contract. Besides, in each stage of implementation, there is a person who is in charge according to the authority and obligations. According to MUDJSANTOSO in his book entitled "KESALAHAN PENGADAAN" published by Primprint publisher, page 101, "There has been a criminal act in procurement if there are elements of FRAUD and FORCE; there is no indication of conspiracy interpreted by GISA". In addition, page 246 mentioned that the presence or absence of OE markup is not based on the comparison of the price in the SPE with the real price of the Purchaser's purchase in the sale and purchase transaction. However, it is based on the official cross-check prices issued by each manufacturer/sole distributor. Hence, in this study, the esearcher found that there is an assumption stating that the performance of the audit conducted by GISA is considered unprofessional since it is influenced by emotions, motives and certain interests that can lead to abuse of authority in the audit mechanism.

\section{Analysis of Resources and Incentives}

Standpoint: resources for the procurement of goods and services consist of human resources, budgetary resources, infrastructure resources and information technology resources. Speaking of human resources and information technology resources and considering that they are intended among other things to avoid the occurrence of conspiracies that may occur among service providers, it is appropriate to use the intended application system, which inevitably results in the main goal of creating the application system. As the consequence of having to use the intended e-procurement application system, the government has freed its users from 
suspicion of fraude, namely conducting conspiracy. As a result, the reason/basis for indications of GISA's conspiracy in determining the State's losses to the procurement is contrary to the principles and systems procurement carried out electronically/e-procurement. It is also contrary to the consequences of the government which obligues the use of an e-procurement application system.

\section{Analysis of communication activities among Oprganization/agency.}

Standpoint: communication activities among organizations/agencies take place through e-procurement, which starts from the users of goods by publishing the plan of needs as well as detailed specifications and total $\mathrm{OE}$ values in writing on e-procurement through LPSE. Ultimately, grounded on tye results of the study, it was found that there is no longer possible collusion or conspiracy among auction participants/providers to condition or win certain auction participants without involving PSU and/or PSU working groups. Besides, communication between $\mathrm{CMO}$ and new providers will occur when the provider has been determined by the working group PSU and/or PSU as the auction winners. In this case, GISA conducts an audit of the procurement referred to the General Hospital of Sanggau regency, without presenting or communicating with the provider regarding the loss of the State specified. Consequently, it contradicts the GISA audit standard, number 7400 regarding the final discussion with the auditee which states, "The auditor should ask for a response/opinion on the results of the audit in addition to not having the final talks with the auditee, in this case, the provider. GISA also did not respond to the response letter from the auditee namely CMO. According to the GISA audit standard, to ensure that an audit report is considered fair, complete, and objective, there should be a review and and response from responsible officials, so that the obtained report does not only express the auditor's conclusions, but also contains the opinions of responsible officials. If the response from the auditee contradicts the conclusions of the audit report, and the auditor perceives that the response is incorrect, it means that the auditor should convey his disapproval of the response along with the balanced and objective reasons. Conversely, the auditor should correct his report if the auditor perceives that the response is correct. According to SUDIRMAN's book (2017: 51-52) entitled "KRIMINALISASI AUDIT", he pointed out that the cause of criminalization by auditors/audit agencies in conducting thw state's financial audits is that audits are not based on audit standards set by the government. Consequently, the results of the study on the analysis of the variable showed that there was a criminalization committed by GISA in conducting audits that were not in accordance with the audit standards set by the government.

\section{Analysis of the Characteristics of the Implementation Institutions}

Standpoint: the characteristics of the implementation institutions, in this case, are formed according to Presidential Regulation No. 54 Year 2010 as amended by Presidential Regulation No. 70 Year 2012. Related to the characteristics of the iplementation institutions in this case, the working groups of PSU and/or PSU which are not declared GISA involved in the intended collusion of GISA. As a result, the conspiracy intended by GISA is a conspiracy between auction participants without involving PSU and/PSU working groups. Meanwhile the procurement is carried out electronically (e-procurement) in which the consequence of 
having to use the intended e-procurement application system leads the government to free the users from the suspicion of doing fraud, namely conspiracy. Hence, the results of the study in this variable analysis indicated that the results of the GISA audit were suspected to be unprofessional and not objective.

\section{Analysis of Economic, Social, and Political Environment}

Standpoint: the economic, social, and political environment that influences the performance of the procurement of surgical medical devices at the General Hospital of Sanggau regency in fiscal year 2014 entails the general hospital environment as the user, as the provider of goods and services, the people who need health services, the Sanggau regency government in carrying out government affairs in the basic services that are their obligations and the political environment of the people's representatives related to the community aspirations and demands for service public in the health sector. In this variable analysis, therefore, there was no connection or influence on the occurrence of legal problems due to the results of the audit conducted by GISA.

\section{Analysis of Response and Disposition of Policy Implementation Apparatus}

Standpoint: the response and disposition of the policy apparatus is revealed by CMO. CMO has explained in detail to the GISA auditor that the results of the GISA audit conveyed in the minutes of audit results are incorrect, but GISA conveyed to the CMO/general hospital to make a response and reveal it in the written form to the head of the GISA representative. Nonetheless, when the CMO conveyed its response in writing to the head of the GISA representative, it turned out that it was not responded. What GISA carries out, in this case, has contradicted the GISA audit standard, namely based on the GISA audit standard. To ensure that an audit report is fair, complete, and objective, there dhould be a review and response from responsible officials so that the obtained report does not only present the auditor's conclusions, but also contains the opinion of the responsible official. If the response from the auditee contradicts the conclusions in the audit report, and the auditor perceives that the response is incorrect, it means that the auditor should convey his disapproval of the response along with the reasons in a balanced and objective manner. On the other hand, the auditor should correct his report if the auditor believes that the response is correct.

For this reason, the results of the research on this variable analysis show that the results of the audit conducted by GISA were made up and emotionally influenced with certain motives and objectives in which it eventually contradicted GISA's audit standards.

\section{Closing}

Based on the results of the study on the implementation of government procurement of goods and services policies, particularly the procurement of surgical medical instruments at the General Hospital of Sanggau regency in fiscal Year 2014 through the implementation of the Van Meter and Van Horn Public Policy Theory, it was found that allegations have resulted in the fact that the existence of parties in the procurement of surgical medical devices at the General Hospital of Sanggau regency in fiscal year 2014 was judged by the alleged criminalization of the audit conducted by GISA. It was revealed in the results of the study 
which were based on available secondary data and the results of the interviews involving 10 informants analyzed by the researcher with 6 Van Meter and Van Horn variables/dimensions on procurement data, provisions in government goods/services procurement in the form of Presidential Regulation No. 54 Year 2010 as amended by Presidential Regulation No. 70 Year 2012; Presidential Regulation No. 16 Year 2016; auction document/Electronic Procurement of Goods and Services Standard issued by PSU Working Group and/or District Government of PSU. Sanggau; LKPP No. 5 Year 2011, LKPP No. 14 Year 2012, a book entitled "KRIMINALISASI AUDIT" by SUDIRMAN, and a book entitled "KESALAHAN PENGADAAN" by MUDJISANTOSO, other documents, including articles on Google.

Basically, the reason for the GISA saying the state lost in the procurement of surgical medical instruments at the General Hospital of Sanggau regency in fiscal year 2014 is due to the emergence of an indication of conspiracy among auction participants referring to the explanation of article 83 paragraph (1) the letter e Presidential Regulation No. 70 Year 2012. Also, it is due to the existence of a dissimilarity in the value of the contract with the value of the real purchase of the provider, including the VAT obtained from the provider purchase invoice. It is contrary to the results of the interviews involving informants in which they stated that since 2013 the government has obligued all M/I/R/O to carry out procurement of government goods and services in full electronic/e-procurement, with the aim of realizing a procurement which is efficient, effective, transparent, open, competitive, fair/non-discriminatory and accountable. As a result, the reason why GISA establishes state losses on the grounds/basis for indications of conspiracy refers to the explanation of article 83 paragraph (1) the letter e Presidential Regulation No. 70 Year 2012 in addition to contradicting the auction system carried out electronically/e-procurement. It is also according to the results of the interviews involving some informants and secondary data in which there have been misinterpretations related to indications of the conspiracy interpreted by GISA which was not appropriate in the explanation of article 83 verse (1) the letter e Presidential Regulation No. 70 Year 2012. Eventually, the reason why GISA stipulates the state losses are due to the interpretations related to the indications of conspiracy carried out improperly or due to the misinterpretation resulting in the determination of State losses carried out by GISA with the inappropriate reasons.

Based on the results of the study, it can be concluded that legal problems that occur as a result of the state losses stipulated in the results of the GISA audit of the procurement of surgical medical devices at the General Hospital of Sanggau regency in fiscal year 2014 are caused by:

1. Misinterpretation related to indications of conspiracy in the explanation of article 83 paragraph (1) the letter e Presidential Regulation No. 70 Year 2012, which GISA conducted;

2. The emergence of assumptions that has been revealed by GISA in the minutes of the audit results used as a basis for determining State losses that are not in accordance with the facts and they are also improper;

3. GISA does not understand the mechanism and system for implementing the government-required procurement carried out electronically (e-procurement). Subsequently, 
the state losses in the procurement of government goods and services are still determined by GISA due to the fact that there are indications of conspiracy referring to article 83 paragraph (1) the letter e of President Regulation No. 70 Year 2012, like what GISA carried out on the procurement manually or conventionally. It is the evidence that article related to indications of conspiracy used by GISA contradicts the procurement system electronically (e-procurement), namely the intended article, has been revoked (eliminated) in the amendment to Presidential Regulation No. 16 Year 2016 because it is contrary to the Electronic procurement (e-procurement) system.

4. Due to the emergence of the state loss calculation method conducted by GISA by finding out the difference between the contract value and the real value of the provider purchase based on the reason for the indication of conspiracy which refers to in the explanation of article 83 paragraph (1) letter e Presidential Regulation No. 70 Year 2012, which was conducted by GISA with erroneous interpretations related to the indication of the conspiracy, the loss of the State determined by GISA is eventually baseless. In addition to contradicting the procurement system electronically/e-procurement, it is also not in accordance with the GISA audit standard. Therefore, it contradicts Law No. 15 Year 2004.

5. The existence of the alleged GISA audit is based on emotions, subjectivity, motives and certain interests. Ultimately, the audit results become unprofessional; they are not objective, and the loss of the state is not feasible. Moreover, the audit results are not considered objective, valid and reliable.

\section{New Concept}

The new concept obtained in this study is: the Implementation of Government Goods and Services Procurement Policies, with the "SO\&R by hari" model, which is in accordance with the principles and ethics of electronic procurement, and is focused on actualizing procurement principles and ethics, including emphasizing the importance of auditing professionalism, so that the audit results can be considered objective, valid and reliable. Its goal is that the implementation of policies for the procurement of goods and services carried out by the government can be in accordance with the objectives of procurement that may generate clean and authoritative governance. In addition, the legal certainty in the procurement of government goods and services can be accounted for by the parties. The model implementation of policies, especially in the procurement of government goods and services can be analyzed with 1 (one) dimension critical variable in implementing government procurement of goods and services, namely dimensions (variables) of policy Standard, Objective \& Resources known as the "SO\&R by hari" model. The model of policy implementation put forward by the researcher is more specific and is focused on the implementation of government procurement of goods and services. In addition to forming relationships between indicators in 1 (one) independent variable, it also makes explicit relations among the indicators on the intended independent variable. The linkages are the hypotheses that can be tested empirically, with the assumption that indicators can be built and the corresponding data can be collected including the implementation proposed by the Van Meter and Van Horn. 


\section{Reference}

Abdul, W. S. (2004). Analisis Kebijaksanaan, Dari Formulasi Ke Implementasi Kebijakan Negara. Jakarta : Bumi Aksara.

Ali, H. F., \& dan Andi, S. A. (2012). Studi Kebijakan Pemerintah, Bandung: Refika Aditama Anderson, J. E. (1984). Public Policy Making - An Introduction (second edition), Texas A \& M University.

Apter, D. (1965). Comperative Politics, The Free Press, New York.

Arikunto, S. (Edisi Revisi 2010). Prosedur Penelitian: Suatu Pendekatan Praktik, Rineka Cipta.

Bahrullah, A. (2015). Sistem Pengawasan Keuangan Negara di Indonesia, Pusat Kajian Keuangan Negara, Jakarta, 2015.

Bailey, C. A. (2007). A Guide To Qualitative Field Research, Thousand Oaks: Pine Forge Press. https://doi.org/10.4135/9781412983204

Bijah, S. (2004). Stratifikasi Kebijaksanaan Nasional, Jakarta Lemhamnas RI, Edisi kedua, cetakan I, 2004

Birkland, T. (2011). An Introduction to the Policy Process: Theories, Concepts, and Models of Public Policy Making, New York: M.E. Sharpe, Inc.

Black, J. A., \& Dean, J. C. (1992). Metode Penelitian Sosial, penerjemah E. Kuswara, Dira Salam \& Alvin Ruzhendi, Bandung: PT Etresco.

Brasz, H. A. (1975). Inleiding tot de Bestuurswetenschap, Vuga Boekerij.

Budi, W. (2007). Kebijakan Publik: Teori dan Proses. Yogyakarta: Media Pressindo.

Bungin, H. M. B. (2007). Penelitian Kualitatif: Komunikasi, Ekonomi, Kebijakan Publik, dan Ilmu Sosial Lainnya, Jakarta: Kencana Penada Media, 2007.

Carl, V. H., \& dan Donal, V. M. (1975). Model-model dalam Kebijakan Implementasi, yongyakarta.

Chase, G. (1979). Implementing a Human Service Program: How Hard Will it Be?. New York City

Cochran, C. E., Lawrence, C., Mayer, T. R., Carr, N., Joseph, C., \& Mark, J. M. (2011). American Public Policy: An Introduction, Boston: Wadsworth.

Cochran, C. L., \& Eloise, F. M. (2010). Public Policy: Perspective and Choices, London: Lynne Rienner Publisher.

Creswel, J. W. (1994). Research Design Qualitative \& Quantitative Approaches. Sage Publication : New Delhi.

Denzim, N. K., \& dan Yvonna, S. L. (1994). Handbook of Qualitative Research. California: 
Sage Publications Inc.

Downs, A. (1967). Inside Bureaucracy, Boston: A Rand Corporation Research. https://doi.org/10.7249/CB156

Dunn, N. W. (2000). Pengantar Analisis Kebijakan Publik. Terjemahan Samodra Wibawa dkk, Yogyakarta: Gajah Mada University Press.

Dye, T. R. (1981). Understanding Public Policy, New Jersey: Prentice-Hall Inc.

Edward III, G. C. (1980). Implementing Public Policy,Congressional Quarterly Inc, USA

Edward, G., \& Sharkansky, I. (1978). The policy Predicament, San Fransisco: W.H. Freeman and company

Gerston, L. N. (2010). Public Policy Making: Process and Principles, New York: M.E. Sharpe, Inc.

Grindle, M. (1980). Politic and policy implementation In the Third World. New Jersey: Princeston University Press. https://doi.org/10.1515/9781400886081

Guess, G. M., \& Paul, G. F. (2011). Case in Public Policy Analysis, Washington: Georgetown University Press, 2011.

Gunawan, I. (2013). Metode Penelitian Kualitatif : Teori dan Praktik, Jakarta: Bumi Aksara, 2013.

Hamdi, M. (2014). Kebijakan Publik: Proses, Analisis, dan Partisipasi. Bogor: Ghalia Indonesia.

Hill, M., \& Peter, H. (2002). Implementing Publik Policy, London: SAGE Publications Ltd.

Hoogerwerf, A. (1978). Ilmu Pemerintahan, Terj.R.L.L. Tobing, Jakarta: Erlangga.

Howlett, M., \& Ramesh, M. (1995). Studying Public Policy, Policy Cycless and Policy Subsytems, New York: Oxford University Press.

Islamy, I. (2000). Prinsip-prinsip Perumusan Kebijakan Publik. Yogyakarta, Bumi Aksara.

Jones, C. O. (1977). An Introduction To The Study of Public Policy Publishing Company Monterey, California: Wesley Longman Publishing Company, Inc.

Kerlinger, F. N. (2002). Asas-asas Penelitian Behavioral, Yogyakarta: Gadjah Mada University Press.

Lan, R. (1997). Sistim Administrasi Negara Republik Indonesia-Jilid I \& II, Jakarta: PT.Toko Gunung Agung.

Mac, I. R. (1947). The Web of Governmen, The Mac Millan Company Ltd., New York.

Marshall, C., \& Rossman, G. B. (1989). Designing Qualitative Research. California: SAGE Publication. Inc. 
Mazmanian, D. A., \& Paul, A. S. (1983). Implementation and Public Policy, IllionisGlenview: Scott, Foresman, \& Co.

Moleong, L. J. (2000). “Metodologi Penelitian Kualitatif”, Bandung: PT. Remaja Rosda Karya.

Mudjisantoso. (2017). "Kesalahan Pengadaan? (Perspektif Hukum)", Yogyakarta : Primaprint Yogyakarta.

Nakamura, R. T., \& Frank, S. (1980). The Politics of Policy Implementation, New York: St. Martin Press, 1980.

Neuman, W. L. (1997). Social Research Methods, London : Needham Heights, Allyn and Bacon.

Neuman, W. L. (2003). Social Research Methods Qualitative and Quantitative Approach, Allyn and Bacon: London.

Nugroho, R. (2009). Public Policy, Jakarta: PT. Elex Media Komputindo.

Poelje, D. G. A. (1953). Algemene Inleiding Tot De Bestuurskunde, Alphen aan den Rijn, N. Samson N.V.

Poelje. (1993). Algemene Inleiding Tot De Bestuurskunde, Alphen aan den Rijn, N. Samson N.V.

Ripley, R. B., \& Franklin, G. A. (1990). Policy Implementation and Bureaucracy (Second Edition), Chicago, Illinois : The Dorsey Press.

Rosenthal, U. (1978). Openbaar Bestuur, Samson HD., Jeenk Willink, Alphen aan den Rijn, Leiden.

Strong, C. F. (1960). Modern Political Constituion, Sidgwick \& Jackson Ltd., London

Strong, C. F. (1960). Modern Political Constitution, Sidswick \& Jacson Limited, London.

Sudirman. (2017). Kriminalisasi Audit Kerugian Keuangan Negara. Medan: Konsultan Audit Kerugian Keuangan Negara.

Sunggono, B. (1994). Hukum dan Kebijaksanaan Publik. Jakarta: Sinar Grafika.

Supriatna, T., \& dan Syaruhdin, Y. (2013). Kebijakan Publik. Bandung: Indra Prahasta.

Syafiie, K. I. (2011). Manajemen Pemerintahan. Pustaka Reka Cipta. Jawa Barat.

Tachjan, H. (2008). Implementasi Kebijakan Publik, Bandung : AIPI.

Taliziduhu, (1997). Metodologi Ilmu Pemerintahan. Jakarta: Rineka Cipta.

Taliziduhu. (1997). Budaya Pemerintahan dan Dampaknya Terhadap Pelayanan Masyarakat. Jakarta. Jurnal Ilmu Pemerintahan Edisi Ketiga.

Taliziduhu.(2003). Kybernology (Ilmu Pemerintahan Baru). Jakarta, Bina Angkasa. 


\section{Macrothink}

Journal of Public Administration and Governance ISSN 2161-7104 2019, Vol. 9, No. 2

Tangkilisan, H. N. S., \& Saputro, S. H. (2003). Implementasi kebijakan publik: transformasi pikiran George Edwards. Lukman Offset: Yayasan Pembaruan Administrasi Publik Indonesia (YPAPI).

Van, M., Donald, S., Van, H., \& Carl, E. (1975). The Policy Implementation Process. A Conceptual Framework. Administration and Society, 6(4). London: Sage Publications, Inc. https://doi.org/10.1177/009539977500600404

Wahab, S. (2014). Analisis Kebijakan (dari formulasi ke penyusunan, Model-model implementasi kebijakan publik), Jakarta Bumi Aksara

Wayne, P. (2001). Pengantar Teori dan Praktik Analisis Kebijakan (Terj. Triwibowo Budi Santoso). Jakarta: Kencana.

Widodo, J. (2007). Analisa Kebijakan Publik. Malang: Bayu Media Publishing

\section{Document}

KUHPerdata

Peraturan Presiden Nomor 54/2010, sebagaimana diubah Peraturan Presiden Nomor 70/2012 dan Peraturan Presiden Nomor 4/2015

Perka LKPP Nomor 5/2011 tentang Standar Dokumen Pengadaan Sistem Secara Elektronik

Risalah Pembicaraan Hasil Audit Pengadaan Alat-Alat Kedokteran Bedah pada RSUD Kabupaten Sanggau Tahun Anggaran 2014 antara Tim BPKP dan Pihak RSUD Sanggau

Surat Tanggapan PPK atas Risalah Pembicaraan Hasil Audit Pengadaan Alat-Alat Kedokteran Bedah pada RSUD Kabupaten Sanggau Tahun Anggaran 2014 antara Tim BPKP dan Pihak RSUD Sanggau

Laporan Hasil Pemeriksaan BPK RI atas Sistem Pengendalian Intern (Buku II) Nomor 17.B/LHP/XIX.PNK/05/2015

Laporan Hasil Pemeriksaan BPK RI atas Kepatuhan Terhadap Peraturan Perundang-Undangan (Buku III) Nomor 17.C/LHP/XIX.PNK/05/2015

Laporan Hasil Audit BPKP Perwakilan Provinsi Kalimantan Barat, Nomor : SR-558/PW14/5/2016 Tanggal 7 Desember 2016

I Gusti Ngurah Suweta. (2016). Implementasi Kebijakan Penanganan Konflik Sosial Berbasis Kearifan Lokal di Kabupaten Karangasem Provinsi Bali. Program Doktor Ilmu Pemerintahan Institut Pemerintahan Dalam Negeri.

Yudhi, W. (2015). Implementasi Kebijakan Pemerintah Terhadap Pengelolaan Pulau-Pulau Terluar - Studi Kasus Pulau Miangas Kabupaten Kepulauan Talaud Provinsi Sulawesi Utara. Program Doktor Ilmu Administrasi, Fakultas Ilmu Sosial dan Ilmu Politik, Universitas Indonesia.

Corneles, S. (2013). Implementasi Kebijakan Lingkungan Hidup di Provinsi Papua. Program 


\section{Macrothink}

Journal of Public Administration and Governance ISSN 2161-7104 2019, Vol. 9, No. 2

Doktor Ilmu-Ilmu Sosial Konsentrasi Ilmu Pemerintahan, FISIP Universitas Padjadjaran Bandung

\section{Copyright Disclaimer}

Copyright for this article is retained by the author(s), with first publication rights granted to the journal.

This is an open-access article distributed under the terms and conditions of the Creative Commons Attribution license (http://creativecommons.org/licenses/by/4.0/). 